Review

\title{
Botulinum Neurotoxins and Botulism: A Novel Therapeutic Approach
}

\section{Jeeraphong Thanongsaksrikul and Wanpen Chaicumpa *}

Laboratory for Research and Technology Development, Department of Parasitology, Faculty of Medicine Siriraj Hospital, Mahidol University, 2 Prannok Road, Bangkok-noi, Bangkok 10700, Thailand; E-Mail: gskmu@ @otmail.com

* Author to whom correspondence should be addressed; E-Mail: tmwcc@ mahidol.ac.th; Tel.: +66-2-419-6497; Fax: +66-2-419-6491.

Received: 8 April 2011; in revised form: 22 April 2011 / Accepted: 28 April 2011 /

Published: 13 May 2011

\begin{abstract}
Specific treatment is not available for human botulism. Current remedial mainstay is the passive administration of polyclonal antibody to botulinum neurotoxin (BoNT) derived from heterologous species (immunized animal or mouse hybridoma) together with supportive and symptomatic management. The antibody works extracellularly, probably by blocking the binding of receptor binding $(\mathrm{R})$ domain to the neuronal receptors; thus inhibiting cellular entry of the holo-BoNT. The antibody cannot neutralize the intracellular toxin. Moreover, a conventional antibody with relatively large molecular size $(150 \mathrm{kDa})$ is not accessible to the enzymatic groove and, thus, cannot directly inhibit the BoNT zinc metalloprotease activity. Recently, a 15-20 kDa single domain antibody $\left(\mathrm{V}_{\mathrm{H}} \mathrm{H}\right)$ that binds specifically to light chain of BoNT serotype A was produced from a humanized-camel $\mathrm{VH} / \mathrm{V}_{\mathrm{H}} \mathrm{H}$ phage display library. The $\mathrm{V}_{\mathrm{H}} \mathrm{H}$ has high sequence homology $(>80 \%)$ to the human $\mathrm{VH}$ and could block the enzymatic activity of the BoNT. Molecular docking revealed not only the interface binding between the $\mathrm{V}_{\mathrm{H}} \mathrm{H}$ and the toxin but also an insertion of the $\mathrm{V}_{\mathrm{H}} \mathrm{H}$ CDR3 into the toxin enzymatic pocket. It is envisaged that, by molecular linking the $\mathrm{V}_{\mathrm{H}} \mathrm{H}$ to a cell penetrating peptide (CPP), the $\mathrm{CPP}-\mathrm{V}_{\mathrm{H}} \mathrm{H}$ fusion protein would be able to traverse the hydrophobic cell membrane into the cytoplasm and inhibit the intracellular BoNT. This presents a novel and safe immunotherapeutic strategy for botulism by using a cell penetrating, humanized-single domain antibody that inhibits the BoNT by means of a direct blockade of the groove of the menace enzyme.
\end{abstract}


Keywords: botulinum neurotoxin; botulism; zinc metalloprotease; immunotherapy; serum therapy; therapeutic antibody; chimeric antibody; humanized antibody; single chain antibody variable fragment $(\mathrm{ScFv})$; heavy chain antibody $(\mathrm{HCAb})$; single domain antibody (sdAb); $\mathrm{VH} ; \mathrm{VL} ; \mathrm{V}_{\mathrm{H}} \mathrm{H}$; humanized-camel phage display library; nanobody; transbody; cell penetrating peptide (CPP); phage display

\section{Introduction}

Botulism is a severe paralytic illness caused by intoxication with botulinum neurotoxins (BoNT) produced by anaerobic bacteria of the genus Clostridium, Clostridium botulinum [1-3]. BoNT is one of the most toxic substances for humans [4]. From primate experiments, the toxin has an extremely low median lethal dose $\left(\mathrm{LD}_{50}\right)$, i.e., $1 \mathrm{ng}$ per $\mathrm{kg}$ body weight [5]. BoNT is transmitted easily by aerosol [5]. Accordingly, the toxin has been attempted by terrorists to use as a biological weapon. BoNT has been designated by the Centers for Disease Control and Prevention (CDC), USA as a category A biological weapon, which is a similar to anthrax in its threat to humans $[4,5]$.

\subsection{Botulinum Neurotoxins (BoNTs)}

There are seven BoNT serotypes designated A-G serotypes (BoNT/A-BoNT/G). C. botulinum, a spore forming, rod shape anaerobic bacterium produces mainly BoNT/A, BoNT/B, BoNT/C, BoNT/D, BoNT/E, and BoNT/F. BoNT/G is solely produced by $C$. argentinense; $C$. butyrium produces BoNT/E, and $C$. baratii produces BoNT/F [1,3]. Among the seven serotypes, BoNT/A is the most potent for humans [2]. Naturally, BoNT is associated to other bacterial proteins, i.e., hemagglutinin (HA) and non-toxic, non-hemagglutinin (NTNH) protein in a form of BoNT-HA-NTNH complex [3]. Although functions of the clostridial HA and the NTNH proteins are still unknown, it is believed that forming a complex with these proteins not only renders the BoNT more resistant to the host gastric acidity, but also facilitates the toxin entry into the blood circulation by undefined mechanism [6,7].

\subsection{Synthesis and Molecular Structure of BoNTs}

BoNT are encoded by bont genes $(\sim 3880 \mathrm{bp})$ which are present on various genetic elements, depending on the species and strains of BoNT-producing clostridia [7]. The bont genes that code for BoNT/A, BoNT/B, BoNT/E and BoNT/F (bont/A, some bont/B, bont/E and bont/F) are located on the bacterial chromosome [7-9]; bont/C and bont/D are derived from bacteriophages [10,11]; and the bont/G and some bont/B genes are present on plasmids [12,13]. Sequence similarity of the bont genes coding for the seven BoNT serotypes ranged from 34\% to 97\% [7].

The molecular structure of BoNTs has been revealed by crystallography as an A-B toxin [14,15]. It is believed that the two polypeptides are synthesized as a single polypeptide which is modified post-translationally by bacterial or host proteases to a $150 \mathrm{kDa}$, active di-chain holotoxin. Each molecule of the toxin is composed of an A subunit or light chain (LC, size $\sim 50 \mathrm{kDa}$ ) which is linked to a B subunit or heavy chain ( $\mathrm{HC}$, size $\sim 100 \mathrm{kDa}$ ) by a single disulfide bond. HC composed of two polypeptide sub-domains, i.e., receptor binding $(\mathrm{R})$ and translocation $(\mathrm{T})$. LC of the BoNT is endowed 
with zinc-dependent metalloprotease activity [16]. Schematic diagram of BoNT/A synthesis is illustrated in Figure 1. The sequence variations of BoNT are in the R domain and the substrate interaction sites of LC domain [14,17].

Figure 1. Schematic diagram of BoNT/A synthesis. Gene coding for BoNT/A (bont/A) synthesized a single polypeptide which is then nicked to form a di-chain active BoNT/A. LC, BoNT/A light chain (residues 1-437); HC, BoNT/A heavy chain (residues 448-1295); $\mathrm{T}$, translcation sub-domain (residues 448-872); R, receptor binding sub-domain (residues 873-1295). A di-sulfide bond is formed by cysteine residues 430 and 454 [18].

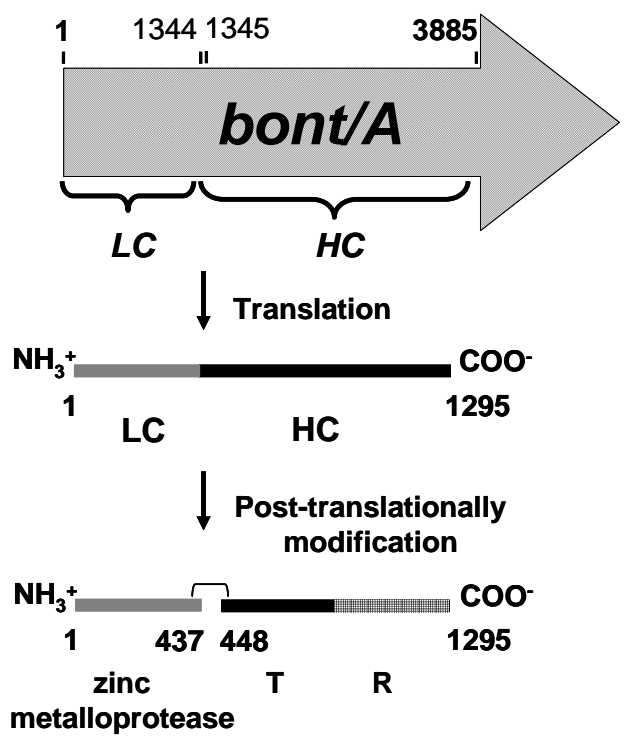

\subsection{Mechanism of Action of BoNTs}

Ingested BoNT absorbed from the intestine, enters lymphatics which are later carried by blood circulation and distributed throughout the host tissues [19]. At a peripheral nerve ending, the $\mathrm{R}$ sub-domain binds to two receptors of the neuron, i.e., low-affinity gangliosides and high-affinity synaptic vesicular proteins [20,21]. The synaptic vesicular proteins that serve as the BoNT receptors are normally located within the lumen of acetylcholine-containing vesicles but become exposed after the neurotransmitter release. Synaptic vesicular proteins that have been identified as BoNT/A and BoNT/B receptors are synaptic vesicular protein-2 (SV2) [22] and synaptotagmin-II (SytII), respectively [20,21]. The BoNT that has bound to the neuronal surface receptors then enters the cell via the receptor-mediated endocytosis (RME). Acidic $\mathrm{pH}$ of the endosome facilitates structural change of the $\mathrm{T}$ sub-domain, which forms a putative pore-like structure [23,24]. The partially or completely unfolded LC translocates across the endosomal membrane via the T-forming pore into the cytoplasm [24,25]. The free LC then refolds and specifically cleaves one of soluble $N$-ethylmaleimidesensitive factor-attachment protein receptor (SNARE) proteins including synaptobrevin (or vesicle associated membrane protein; VAMP) which anchors on outer shell of synapticular vesicle, synaptosomal-associated protein of $25 \mathrm{kDa}$ (SNAP25), and syntaxin. The latter two are associated with the inner leaflet of the neuronal plasma membrane [26]. BoNT/A, BoNT/C and BoNT/E cleave SNAP25 at different peptidase sites [27-29]. BoNT/C also digests syntaxin [25,30,31]. BoNT/B, 
BoNT/D, BoNT/F, and BoNT/G cleave synaptobrevin [7]. Table 1 gives details on the target SNARE proteins of the BoNTs and their specific endopeptidase cleavage sites. The cleavage of SNARE proteins, which are neurotransmitter exocytosis machinery, leads to abolition of the membrane fusion between neurotransmitter-containing vesicles and the neuronal plasma membrane, and eventually blocks acetylcholine release to neuromuscular junction, resulting in weakness of muscles or flaccid paralysis; the disease which is called botulism [5,26].

Table 1. Cleavage sites of different BoNTs on the human SNARE proteins [18].

\begin{tabular}{llll}
\hline BoNT Serotype & SNARE Substrate(s) & Susceptible Scissile Bond & Reference(s) \\
\hline A & SNAP25 & Gln197-Arg198 & {$[27-29]$} \\
C & SNAP25 & Arg198-Ala199 & {$[30,31]$} \\
& Syntaxin & Lys253-Ala254 and & {$[25,30,31]$} \\
& & Lys260-Ala261 & \\
E & SNAP25 & Arg180-Ile181 & {$[28,29]$} \\
B & VAMP & Gln76-Phe77 & {$[32]$} \\
D & VAMP & Lys59-Leu60 & {$[28,34]$} \\
F & VAMP & Gln58-Lys59 & {$[33,34]$} \\
G & VAMP & Ala81-Ala82 & {$[35]$} \\
\hline
\end{tabular}

\subsection{Botulism}

Botulism is the weakness of the affected striated muscles (flaccid paralysis) due to the BoNT mediated blockade of the release of acetylcholine neurotransmitter from pre-synaptic neuron into the neuromuscular junction [26]. Human botulism is caused by BoNT/A, BoNT/B, BoNT/E, and occasionally BoNT/F. Domesticated animals including dogs, cattle, birds, and chickens are affected by BoNT/C. BoNT/D can cause the disease in cattle. There has been no reported case of human or animal botulism associated with BoNT/G [3,5,36].

Four clinical types of human botulism have been identified. They are: food-borne-, infant-, wound- and inhalational botulism [5]. Food-borne botulism is manifested after ingesting improperly cooked, preserved or stored foods, especially canned food containing preformed BoNT. Under anaerobic conditions, bacterial spores that have contaminated the food germinate and release the BoNT by a cell-wall exfoliation mechanism. Unlike food-borne botulism, infant botulism is caused by BoNT released from growing clostridia that colonize in infant's intestine [1,5]. In wound botulism, clostridia colonizes an infected injured tissue, produce toxins which later absorbed into the bloodstream of the host, and subsequently reach the neuromuscular junctions [1,5]. The inhalational form of botulism is man-made and caused by inhalation of the BoNT powder, which is aerosolized and transmitted to victims for the purpose of bioterrorism [5]. Among the four types, food-borne botulism is the most common type [1,5]. Clinical manifestations of the food-borne botulism usually begin 12 to $48 \mathrm{~h}$ after ingesting the food contaminated with the preformed BoNT [5,7].

\subsection{Clinical Manifestations of Human Botulism [5,36]}

All forms of human botulism present mostly identical neurological signs because all BoNT mediate similar physiological abnormalities in the peripheral nervous system. However, the neurological signs 
in food-borne botulism may include abdominal cramps, nausea, and vomiting. The neurological form is characterized by symmetrical, descending, and flaccid paralysis of parasympathetic nerves. The symptoms usually begin with cranial nerve (face) palsies, including drooping of the upper eyelids (ptosis), double vision (diplopia), blurred vision, difficulty in articulating words (dysarthria), difficulty in speaking (dysphonia), and difficulty in swallowing (dysphagia). The paralysis then develops to general weakness of several muscles such as arms, legs, and diaphragm which may lead to fatality if not treated properly and promptly. The severity of the disease varies from individual to individual and depending upon the amount of toxins consumed and absorbed [5].

\section{Treatment of Botulism}

Presently, there is no licensed BoNT antagonist, although several attempts have been made to invent the toxin inhibitors. Mouse monoclonal antibodies to BoNT light chain were unable to neutralize the BoNT mediated lethality in mice, although the antibodies injected intracellularly into nerve ganglion prior to the BoNT administration were found to prevent the BoNT mediated inhibition of neurotransmitter exocytosis in Aplysia [37]. Small molecular inhibitors of $S_{1}$ subsite of type B BoNT metalloprotease were shown to inhibit the BoNT activity in vitro [38,39]. However, due to their inability to cross plasma membrane, none of them have reached the clinical trial for the human therapeutic value.

The treatment of botulism is based on supportive measures including artificial respiration and passive administration of human and animal (mainly horse) derived anti-BoNT immune globulin (polyclonal antibodies; PAb) to the afflicted individual [5]. Immune sera and antibody preparations that have been used for treatment of human botulism are listed in Table 2.

Table 2. Various anti-BoNT preparations for current therapeutic use.

\begin{tabular}{|c|c|c|c|c|}
\hline Preparation & $\begin{array}{l}\text { Target BoNT } \\
\text { Serotype }\end{array}$ & Enterpreneur & Status & Reference(s) \\
\hline $\begin{array}{l}\text { 1. Trivalent equine } \\
\text { antitoxin }\end{array}$ & $\mathrm{A}, \mathrm{B}$, and $\mathrm{E}$ & $\mathrm{CDC} / \mathrm{USA}$ & FDA approved & {$[36,40]$} \\
\hline $\begin{array}{l}\text { 2. Bivalent equine } \\
\text { antitoxin (BAT-AB) }\end{array}$ & $\mathrm{A}$ and $\mathrm{B}$ & Sanofi Pasteur Limited & FDA approved & {$[41,42]$} \\
\hline $\begin{array}{l}\text { 3. Human botulism } \\
\text { immune globulin } \\
\text { (BabyBIG or BIG-IV) }\end{array}$ & $\mathrm{A}, \mathrm{B}, \mathrm{C}, \mathrm{D}$, and $\mathrm{E}$ & $\begin{array}{l}\text { California Department } \\
\text { of Public Health }\end{array}$ & FDA approved & [41-44] \\
\hline $\begin{array}{l}\text { 4. Monovalent equine } \\
\text { antitoxin (BAT-E) }\end{array}$ & $\mathrm{E}$ & Sanofi Pasteur Limited & Investigational & [41] \\
\hline $\begin{array}{l}\text { 5. Heptavalent equine } \\
\text { antitoxin (HBAT) }\end{array}$ & A to $G$ & Cangene Corporation & Investigational & [41] \\
\hline 6. Recombinant antitoxin & A & $\begin{array}{l}\text { University of California, } \\
\text { San Francisco }\end{array}$ & Investigational & {$[36,45-47]$} \\
\hline
\end{tabular}

There are some limitations in using the immunized human/animal derived antitoxin. It is believed that the PAb derived from the immune serum can only block the circulating BoNT from cellular entry by inhibiting the binding of the toxin to the neuronal cell surface receptors $[48,49]$. They cannot 
traverse the plasma membrane. The preparation usually contains a relatively small proportion of specific immunoglobulins. Moreover, the animal-derived anti-BoNT is foreign to the human immune system. Therefore, not only are the antibodies speedily eliminated from the recipient's body (hence large amount of the therapeutic antibodies are required to resuscitate the patient), but also the animal proteins elicit anti-animal isotypic response leading to adverse reactions which may be as serious as acute anaphylaxis and/or serum sickness [5]. The latter is mediated by immune complexes formed in the condition of the antigen (animal protein) excess. Besides, the supply and availability of the antitoxin are relatively limited because a prolonged immunization process is required before a satisfactory level of the antitoxin is reached in the sera. The quality of the BoNT neutralizing antibodies obtained in this way is subjected to batch-to-batch variation. The human recipient is also at a risk of anthroponosis/zoonosis. Therefore, alternative approaches for producing the botulism therapeutic antibody should be sought.

\section{Therapeutic Antibody}

\subsection{Serum Therapy}

Antibody has been used since the early nineteenth century in passive immunization for disease prevention and intervention as well as for therapeutic purposes [50]. The medical practice was then called "Serum therapy". The therapeutic preparations were either immune serum or immunoglobulins derived from plasma or serum of healthy, vaccinated and/or disease convalescent humans. For example, the serum of a human immunized with tetanus toxoid was used for treatment of tetanus [51]; and the serum of a convalescing measles patient was used in the intervention of measles morbidity in an immunocompromised child who had been exposed to the measles virus [52]. The immunoglobulin/antibody therapeutic role include restoration of the immunoglobulin functions in the immunodeficient subjects, toxin/enzyme neutralization, prevention of pathogen attachment to host cell/tissue and colonization, prevention of cellular entry, inhibition of motility, promotion of phagocytosis by means of opsonization followed by killing, immune exclusion, antibody dependent cell mediated cytotoxicity (ADCC) by natural killer (NK) cells and antibody-complement mediated lysis of pathogens or infected host cells [53-58]. Limitations in using human derived antibody include the scarcity of donors, variation in antibody quality, and recipient risk to some blood-borne anthroponosis. The practice is also unethical. Thus, therapeutic antibodies were from immunized animals such as horse or sheep. Nevertheless, there are still problems in production and use of the animal-derived antibody. Repetitive immunizing doses and a prolonged immunization process (more than 6 months or a year) are required before a satisfactory level of antibody is obtained from the plasma/serum of the immunized animal. There is a batch-to-batch variation in the antibody quality. Using in vivo immunization, it is difficult to produce immune serum for low immunogenic and/or highly toxic molecules (such as snake neurotoxin), for which the immunogenic dose is much higher than the toxic/lethal dose, similarly for small molecular hapten that contain only B cell epitope, such as puffer fish tetrodotoxin ( 320 Da). Besides, large animals require a large amount of space and care. Animal immune serum contains a large proportion of non-specific serum proteins/immunoglobulins. Most of all, animal proteins are foreign and highly immunogenic to the human immune system, often 
leading to allergic reactions such as anaphylaxis and serum sickness-the latter is caused by human anti-animal isotypic antibodies which form an immune complex with the animal proteins. The recipient is also at risk of zoonosis.

\subsection{Mouse Monoclonal Antibody}

The invention of hybridoma technology by Köhler and Milstein (subsequent recipients of Nobel Laureates) in 1975 [59] has abrogated many limitations in preparing and using the animal immune serum. The mouse monoclonal antibody (MAb) with high purity, defined specificity, and reproducible affinity [60] can be obtained easily, rapidly, and adequately without frequent/repeated and prolonged immunization process but merely by growing an established hybridoma clone in a culture medium. The recipients of the MAb are relatively safe from zoonosis as the MAb can be obtained from the spent culture medium of a hybridoma grown in a serum free medium. Nowadays, murine MAb have been used as therapeutic agents against cancers, autoimmune, inflammatory conditions, infectious diseases, and intoxications [53,61]. Currently, about 30 therapeutic antibodies have been approved by FDA for marketing in the United States and over $200 \mathrm{MAb}$ candidates are in the pipeline [62,63]. Recently, MAb specific to HC of BoNT subtype A1 were produced [64]. The MAb and its pegylated $\mathrm{F}(\mathrm{ab})$ '2 not only neutralized the BoNT activity but could rescue the intoxicated mice from the toxin mediated lethality [64]. Nevertheless, limitations in production of MAb include requirement of tissue culture facility. Often the culture is contaminated and the hybrid clone loses the immunoglobulin genes [65]. Biologically, the mouse MAb is foreign to the human immune system and the human antibody to mouse antibody (HAMA) is produced inevitably which also leads to adverse effects [66-68]. Ideally, an antibody with minimal- or, to the best, no immunogenicity to the human immune system is needed for human therapy.

\subsection{Chimeric-, Humanized- and Single Chain Antibodies}

The first attempt to reduce immunogenicity of the mouse MAb in the human recipient was to produce a human-mouse chimeric antibody [69]. The Fc portion of the mouse antibody was replaced by the human counterpart in the chimeric molecule by genetic engineering. The $\mathrm{Fc}$ is required to retain effective therapeutic mechanisms (Section 3.1) and longevity as well as for clearing the immune complexes by means of Fc-dependent phagocytosis. The chimeric antibody retains the original antigenic (epitopic) specificity of the mouse MAb but about $70 \%$ or more of the molecule is human protein [70]. F(ab)' ${ }_{2}$, Fab or single chain antibody fragments $(\mathrm{ScFv}$; VH linked to VL by a short polypeptide) can be used in human therapy when the bio-function of the Fc in mediating the therapeutic effect is not needed. Clearance of the immune complexes formed by these antibody fragments can be mediated by Fc-independent phagocytosis [71,72]. The immune aggregates and small molecules (e.g., free $\mathrm{ScFv}$ ) may be filtered through glomeruli for which the filtration cut-off is approximately $60 \mathrm{kDa}$ [73]. However, HAMA is still produced against the mouse antibody fragments [66,67]. Further reduction of the immunogenicity of the mouse protein in the human recipient has been done by replacing the mouse immunoglobulin frameworks (FRs) with the best matched human counterparts. This can be done by the molecular grafting of all of the mouse complementary determining region (CDR) coding sequences onto the DNA sequences of human FRs; 
the process is called "Humanization" [74,75]. The humanized-mouse monoclonal antibody fragments such as $\mathrm{ScFv}$ retain the original epitopic specificity, but the mouse protein is contained only in the CDRs and is unlikely to be immunogenic in humans. The first chimeric (antithrombolism) and humanized (immunosuppressant) antibodies for human use were approved by the FDA in 1994 and 1997, respectively [76]. For anti-BoNT, several chimeric, humanized and ScFv are currently in pre-clinical evaluation [45-47].

\subsection{Fully Human Monoclonal Antibody}

The production of fully human therapeutic monoclonal antibody is possible nowadays by using several approaches. Transgenic mice carrying human immunoglobulin genes can be immunized with an antigen. The animals produce human polyclonal antibodies which are the products of the human immunoglobulin transgenes [77]. However, the supply of the human polyclonal antibodies from the transgenic mice is limited and expensive and thus they are limited to research purposes. Spleen cells of the immunized transgenic mice can be fused with mouse myeloma cells, and hybridomas secreting human monoclonal antibodies can be produced by conventional hybridoma technology. However, the transgenic facility and the cost of transgenic mice are hardly affordable by most developing countries. The alternative production of a fully human monoclonal antibody is done by infecting human immune B lymphocytes from immunized/disease convalescing subjects with Epstein-Barr (EB) virus [78-80]. The virus transforms the $\mathrm{B}$ cells into immortalized cells which can be grown individually in tissue culture for human monoclonal antibody production. Nevertheless, the EB transformed B cells frequently lose the ability to secrete the MAb [81].

Theoretically, the human immune system can generate approximately $10^{12}$ of antibody diversity from a rather limited immunoglobulin gene repertoire by means of several notated mechanisms including: the use of multiple germ-line gene segments, combinatorial V-(D)-J joining, junctional flexibility of coding joints, P-region nucleotide addition, $\mathrm{N}$-region nucleotide insertion for $\mathrm{H}$ chains, combinatorial association of $\mathrm{L}$ and $\mathrm{H}$ chains, and somatic hypermutation and affinity maturation in secondary lymphoid tissues [82,83].

Contemporary technology in molecular biology and molecular immunology such as antibody engineering also allows the possibility of making a specific human antibody with relatively high affinity to a target molecule in vitro (without the in vivo immunization). For instance, the human immunoglobulin gene repertoire could be generated in vitro by cloning the antibody coding genes from B lymphocytes of naïve or specifically immunized donors into a display system, such as cell [84-86], ribosome [87], and phage [88] to construct the so-called "Human antibody display library" [89,90]. Among these display systems, phage is the most commonly used for constructing the antibody display library [89]. The antibody molecules; mostly in the fragment formats (Fab, ScFv, single antibody domain) [91], are displayed on the surface of fd or M13 filamentous bacteriophages which the phenotype of each displayed molecule is correlated to the genotype of the encoding DNA in the phage genome [92]. To construct such a recombinant antibody phage display library, a pool of differently rearranged immunoglobulin genes is amplified and cloned into a phagemid vector (a plasmid containing a phage origin of replication). The translation frame of the gene is positioned next to gIII or gVIII, which code for phage pIII minor coat protein and pVIII major coat protein respectively [93,94]. 
There is an amber stop codon (TAG) incorporated between the inserted antibody gene and gIII or gVIII [93]. In the suppressor E. coli strain, the suppressor tRNA is produced, which allows reading through the amber codon so that the antibody is displayed on the phage surface by fusing with the pIII or pVIII protein [93]. In contrast, non-suppressor E. coli strain does not produce such a tRNA; thus the recombinant antibody is secreted alone without the pIII or pVIII phage partner [93]. The recombinant phagemid-carrying antibody gene insert will replicate in the suppressor E. coli. Mature phage (complete) phage particles are obtained after co-infecting the cultured phagemid transformed E. coli with a helper phage such as M13K07, so called "Phage rescue" process. The newly assembled recombinant phage particles display the antibody molecules on their surface as pIII- or pVIII-fusion protein. The co-infection of the recombinant phagemid transformed E. coli with the helper phage is indispensible because the phagemid genome only encodes the pIII or pVIII fusion proteins without other genes for all other essential structural phage proteins; thus the mature phage particles cannot be produced. The phage structural proteins must be provided by the helper phages. The helper phages also help in packaging the replicating recombinant phagemids into the capsid. After phage rescuing, some new helper phages could be obtained in the phage library [93]. Nevertheless, they are less competitive for assembling into complete particles than the recombinant phagemids because of their defect in the origin of replication [93].

A phage that displays an antibody to a particular antigen can be directly isolated from the constructed antibody phage display library by means of "Bio-panning". An antigen is immobilized on a solid phase, such as cell surface, beads, or wells of ELISA plate. The antigen binds with the displayed-antibody molecule on the phage particle. The antigen-unbound phages are removed simply by extensive washing with a buffer such as phosphate buffered saline (PBS) containing a mild detergent, e.g., Tween-20 (PBST). The antigen-bound phages can be eluted, further amplified in the suppressor E. coli and rescued from the culture after adding the helper phage. They can be subjected to repeated bio-panning rounds in order to enrich the high affinity binders [93]. Alternatively, the antigen-bound phages from the single bio-panning round can be added directly with a non-suppressor strain of $E$. coli host cells to allow phage transfection into the bacteria. In our laboratory, this "Single round bio-panning" has been used successfully for the selection of recombinant phage clones that display specific antibodies to a variety of target molecules [90,95-97]. In the E. coli transfection, each recombinant phage uses the unoccupied pIII molecule(s) to bind to the bacterial F pilus. The latter serves as a molecular tube through which the phagemid genome with the antibody gene insert enters the bacterial cytoplasm. The phage-transfected E. coli colonies grow on a selective agar plate and can be selected appropriately [90,95-97]. The selected transformed non-suppressor E. coli can be grown under an induction condition (usually by isopropyl $\beta$-D-1-thiogalactopyranoside; IPTG) to express the soluble recombinant antibody molecules with fusion tags such as E-tag. The tagged recombinant antibody can be detected and purified easily by using anti-tag monoclonal antibody as the capture reagent. The bacterial expression system allows a production of the fully human recombinant antibody at the desired quantity without the in vivo immunization $[93,98]$. In addition, the antibody coding gene can be subcloned from the phagemid into other appropriate vectors for antibody production by other cellular factories such as insect, yeast and mammalian. The antibody display technology allows also the production of antibodies to low immunogenic, non-immunogenic and/or toxic molecules which are highly difficult, if possible, by a conventional immunization method. The in vitro production is free 
from an in vivo immune regulation and feedback mechanism. The antibody recipient is safe from zoonosis. Moreover, the antibody production is free from the animal ethic and welfare concern.

\subsection{Single Domain Antibody (sdAb)}

Serum of some camelids, i.e., Camelus dromedarius (one hump Arabian camel), llama (Lama glama and L. guanicoe) and alpaca (Vicugna pacos) contains both a conventional four-chain antibody and an atypical antibody, called "Heavy-chain antibody (HCAb)" the molecule of which does not contain a light chain. Instead, two heavy chain molecules tend to be associated by non-covalent bonding [99]. HCAb has one antigen-binding site per molecule and this is contributed by the heavy chain variable domain designated " $\mathrm{V}_{\mathrm{H}} \mathrm{H}$ " instead of the typical $\mathrm{VH}$ and $\mathrm{VL}$ of the conventional four-chain antibody. Because the HCAb lacks VL, the hydrophobic amino acids V42, G49, L50, and W52 of the conventional VH where the VL partner used to associate were replaced by hydrophilic counterparts, i.e., $\mathrm{F} / \mathrm{Y} 42$, E49, R/C50, and G/L52 in the FR2 of the $\mathrm{V}_{\mathrm{H}} \mathrm{H}$ in order to reduce molecular aggregation and increase serum solubility of the HCAb [100,101]. The amino acid tetrad is a hallmark that allows distinction to be made between the $\mathrm{V}_{\mathrm{H}} \mathrm{H}$ of $\mathrm{HCAb}$ and the conventional $\mathrm{VH}$.

Diversity of the $\mathrm{HCAb}$ repertoire is generated from the germline immunoglobulin DNA by the same mechanisms as for humans and mice, except that the combinatorial $\mathrm{H}-\mathrm{L}$ chain pairing is absent because of the lack of the L chain partners [102,103]. The HCAb diversity was from: multiple germ-line gene segments, combinatorial V-D-J joining, junctional flexibility, P-nucleotide addition and $\mathrm{N}$-nucleotide insertion. Somatic hypermutation and affinity maturation also occur in the secondary lymphoid tissues [103]. The camelid immune system compensates for the absence of combinatorial H-L chain pairing by using several other strategies which have been described in more detail elsewhere [103]. Briefly, the $\mathrm{HCAb} \mathrm{V}_{\mathrm{H}} \mathrm{H}$ segments have expanded surface for antigen-contact especially in the CDR1 and CDR3 [102]. CDRs of the $\mathrm{V}_{\mathrm{H}} \mathrm{H}$ are unusually longer than the CDRs of the conventional $\mathrm{VH}$; for example, CDR1 and CDR3 of VH have 5 and 12 amino acids respectively, while $\mathrm{V}_{\mathrm{H}} \mathrm{H}$ CDR1 and CDR3 have 8 and 16-18 amino acids respectively [103,104]. It is believed that the longer CDR3 of camel $\mathrm{V}_{\mathrm{H}} \mathrm{H}$ is facilitated by an increased activity of the TdT enzyme ( $N$-nucleotide insertion) during the V-D-J joining [105]. Besides, there are several hotspots for somatic mutations by the oligonucleotide insertions and deletions in $\mathrm{V}_{\mathrm{H}} \mathrm{H}$ DNA which are frequently found at CDR1 and CDR2 [102,105]. Moreover, the camel $\mathrm{V}_{\mathrm{H}} \mathrm{H}$ segments have structural hypervariability of the antigen binding loops created by non-canonical extra-loop disulfide bonds in the CDRs, including CDR3 intra-loop disulfide bonds and the inter-loop disulfide bonds that link the CDR3 with CDR1 or CDR2 and with FR2 [100,106].

\section{Molecular Insertion of a Single Domain Antibody (sdAb) into the Enzymatic Groove Directly Inhibits BoNT Zinc Metalloprotease Activity: A Novel and Specific Immunotherapeutic Approach to Botulism}

CDR3 of $\mathrm{V}_{\mathrm{H}} \mathrm{H}$ has been shown to be penetrable into an active-site pocket of a target enzyme which would never be reached by a large, conventional antibody $[106,107]$. Consequently, the camelid $\mathrm{V}_{\mathrm{H}} \mathrm{H}$ antibody fragments have been shown to be potent enzyme inhibitors [108,109]. Because of its characteristics [small size ( 15-20 kDa), high tissue-penetrating ability, high yield from an expressed 
system such as E. coli (5-10 $\mathrm{mg}$ per $\mathrm{mL}$ ), and high stability], the single domain antibody (sdAb) has drawn much attention regarding its use as a therapeutic antibody in human cancers, infectious diseases, and intoxications, particularly those caused by toxic enzyme molecules [97,110,111] or toxic small molecules such as puffer fish tetrodotoxin [112]. The camel $\mathrm{V}_{\mathrm{H}} \mathrm{H}$ (Nanobody ${ }^{\circledR}$, Ablynx) specific to von Willebrand factor has been found to be safe in human subjects (no adverse reaction) in the phase I clinical trial [62]. The safety should be due to the high degree of sequence homology between human $\mathrm{VH}$ and camel $\mathrm{V}_{\mathrm{H}} \mathrm{H}$ immunoglobulin frameworks (FRs) which is $>80 \%$ [111]. The small size of the antibody is necessary not only for high tissue penetrating ability but also in having a more defined antigen binding site than the Fv of the conventional antibody or recombinant ScFv [113].

Recently, we have constructed a humanized-camel $\mathrm{VH} / \mathrm{V}_{\mathrm{H}} \mathrm{H}$ phage display library [97]. Complementary DNA prepared from mRNA of a Camelus dromedrarius was used as a template for PCR amplification of the gene sequences coded for camel $\mathrm{VH} / \mathrm{V}_{\mathrm{H}} \mathrm{H}$. However, primers used in the PCR amplification were degenerate primers designed from all families of human $\mathrm{VH}$ and $\mathrm{JH}$ sequences including VH 1a, 1b, 1c, 1d, 2a, 2b, 3a, 3b, 3c, 4a, 4b, 5a, 6a and 7a and JH3, J6 and J1245 [90]. The human primers created an amplification constraint during the polymerase chain reaction which only the human-like camel $\mathrm{VH} / \mathrm{V}_{\mathrm{H}} \mathrm{H}$ (humanized) sequences were amplified [97]. $\mathrm{V}_{\mathrm{H}} \mathrm{H}$ that bound specifically and neutralized the enzymatic activity to BoNT/A light chain was produced from a non-suppressor $E$. coli clone carrying recombinant $\mathrm{V}_{\mathrm{H}} \mathrm{H}$-phagemid that had been selected from the humanized-camel $\mathrm{VH} / \mathrm{V}_{\mathrm{H}} \mathrm{H}$ display library. The epitope of the $\mathrm{V}_{\mathrm{H}} \mathrm{H}$ was found to be a peptide located at the immediate vicinity of the BoNT/A enzymatic active site. Molecular docking and interface binding revealed that the $\mathrm{V}_{\mathrm{H}} \mathrm{H}$ inserted its CDR3 into the toxic metalloprotease cleft [97]. The $\mathrm{V}_{\mathrm{H}} \mathrm{H}$ has high sequence homology to the human $\mathrm{VH}$ sequences [97]. Therefore, the single domain antiBoNT/A antibody should have high potential as a safe, as well as effective and specific therapeutic remedy for human botulism caused by the type A BoNT. Recently, $\mathrm{V}_{\mathrm{H}} \mathrm{H}$ specific to toxoid of BoNT/A was also produced from a phage display library constructed from B cells of a non-immune llama [114] as well as a llama immunized with the BoNT toxoid [115]. It is known, however, that there are sequence variations of the BoNT catalytic domain within the areas near to the enzymatic groove, and these variations have contributed to substrate specificity of different BoNT subtypes. Thus the humanized $\mathrm{V}_{\mathrm{H}} \mathrm{H}$ that blocks the enzymatic activity of BoNT/A subtype should not cross-neutralize the other BoNT subtypes. Nevertheless, the same strategy [97] can be applied for production of humanized-camel $\mathrm{V}_{\mathrm{H}} \mathrm{H}$ that inhibit other BoNT subtypes.

\section{Cell Penetrating Antibody (Transbody)}

It is known that the enzymatic active site of the BoNT light chain is only exposed after the light chain has been released into the cytoplasm of the affected neuronal cells [14]. Therefore, the BoNT enzymatic cleft is inaccessible by the extracellular antibody. This problem can be overcome by making the $\mathrm{V}_{\mathrm{H}} \mathrm{H}$ into a cell-penetrating format or "Transbody". For this procedure, $\mathrm{V}_{\mathrm{H}} \mathrm{H}$ is linked molecularly to a suitable cell-penetrating peptide (CPP) [116-118]. CPP is a short peptide that can be conjugated to various cargo molecules including proteins, antibody, nucleic acids, plasmid, and siRNA [119]. The CPP directs its cargo (in the form of a chimeric molecule) into the cytosol without causing cellular damage [118] by as yet unknown mechanism(s) [120-124]. CPPs have become a promising vehicle for 
cellular uptake of therapeutic molecules [125]. In addition, CPP sequences can be modified for delivering the cargoes to different subcellular compartments [126]. Various CPPs and their amino acid sequences have been listed elsewhere [127]. Recently, a cpp-plasmid platform has been established in our laboratory [118]. The coding sequence of the $\mathrm{V}_{\mathrm{H}} \mathrm{H}$ that has been shown to inhibit the BoNT enzymatic activity can be molecularly linked to a CPP coding sequence using the plasmid platform. The CPP- $\mathrm{V}_{\mathrm{H}} \mathrm{H}$ fusion protein is expected not only to traverse across the neuronal cell membrane into the cell but also to retain the BoNT inhibitory activity which would block the intracellular enzymatic target. This approach has high potential as a novel and specific immunotherapeutic strategy for human botulism.

\section{Conclusions}

Treatment of human botulism is supportive and symptomatic. Passively administered animal-derived anti-BoNT neutralizes circulating botulinum neutrotoxin by inhibiting binding of the toxin to neuronal receptors. The antibody cannot inhibit directly the proteolytic activity of the toxin that has gained cellular entry. In order to be mostly effective the anti-BoNT must be given at the earliest phase of the illness. The supply of the antitoxin is limited and not always available. Moreover, the animal protein induces adverse reactions in the recipient. A humanized single domain monoclonal transbody (cell penetrating $\mathrm{V}_{\mathrm{H}} \mathrm{H}$ ) that binds and blocks the zinc metalloprotease activity of the intracellular BoNT specifically and directly, and does not cause the undesirable side effects, should be a novel and better immunotherapeutic remedy for human botulism.

\section{Acknowledgments}

We acknowledge with thanks the financial support from The National Research University Grant from the Commission on Higher Education (CHE) through Center of Biopharmaceutical Development and Innovative Therapy, Mahidol University; DPG5380001, Thailand Research Fund; and Research Group Grant 2006, CHE, Thailand.

\section{References}

1. Sugiyama, H. Clostridium botulinum neurotoxin. Microbiol. Rev. 1980, 44, 419-448.

2. Gill, D.M. Bacterial toxins: A table of lethal amounts. Microbiol. Rev. 1982, 46, 86-94.

3. Hatheway, C.L. Toxigenic clostridia. Clin. Microbiol. Rev. 1990, 3, 66-98.

4. Rotz, L.D.; Khan, A.S.; Lillibridge, S.R.; Ostroff, S.M.; Huhge, J.M. Public health assessment of potential biological terrorism agents. Emerg. Infect. Dis. 2002, 8, 225-230.

5. Arnon, S.S.; Schechter, R.; Inglesby, T.V.; Henderson, D.A.; Bartlett, J.G.; Ascher, M.S.; Eitzen, E.; Fine, A.D.; Hauer, J.; Layton, M.; Lillibridge, S.; Osterholm, M.T.; O’Toole, T.; Parker, G.; Perl, T.M.; Russell, P.K.; Swerdlow, D.L.; Tonat, K. Botulinum toxin as a biological weapon: Medical and public health management. JAMA 2001, 285, 1059-1070.

6. Fuginaga, Y.; Matsumura, T.; Jin, Y.; Takegahara, Y.; Sugawara, Y. A novel function of botulinum toxin-associated proteins: HA proteins disrupt intestinal epithelial barrier to increase toxin absorption. Toxicon 2009, 54, 583-586. 
7. Poulain, B.; Popoff, M.R.; Molgo, J. How to botulinum neurotoxins block neurotransmitter release: From botulism to the molecular mechanism of action. The Botulinum J. 2008, 1, 14-56.

8. Whelan, S.M.; Elmore, M.J.; Bodsworth, N.J.; Brehm, J.K.; Atkinson, T.; Minton, N.P. Molecular cloning of the Clostridium botulinum structural gene encoding the type B neurotoxin and determination of its entire nucleotide sequence. Appl. Environ. Microbiol. 1992, 58, 2345-2354.

9. Sebaihia, M.; Peck, M.W.; Minton, N.P.; Thomson, N.R.; Holden, M.T.G.; Mitchell, W.J.; Carter, A.T.; Bentley, S.D.; Mason, D.R.; Crossman, L.; et al. Genome sequence of a proteolytic (Group I) Clostridium botulinum strain Hall A and comparative analysis of the clostridial genomes. Genome Res. 2007, 17, 1082-1092.

10. Inoue, K.; Iida, H. Conversion of toxigenicity in Clostridium botulinum type C. Jpn. J. Microbiol. 1970, 14, 87-89.

11. Eklund, M.W.; Poysky, F.T.; Reed, S.M. Bacteriophage and the toxigenicity of Clostridium botulinum type D. Nat. New Biol. 1972, 235, 16-17.

12. Eklund, M.W.; Poysky, F.T.; Mseitif, L.M.; Strom, M.S. Evidence for plasmid-mediated toxin and bacteriocin production in Clostridium botulinum type G. Appl. Environ. Microbiol. 1988, 54, 1405-1408.

13. Franciosa, G.; Maugliani, A.; Scalfaro, C.; Aureli, P. Evidence that plasmid-borne botulinum neurotoxin type B genes are widespread among Clostridium botulinum serotype B strains. PLoS ONE 2009, 4, e4829.

14. Lacy, D.B.; Tepp, W.; Cohen, A.C.; DasGupta, B.R.; Stevens, R.C. Crystal structure of botulinum neurotoxin type A and implications for toxicity. Nat. Struct. Biol. 1998, 5, 898-902.

15. Swaminathan, S.; Eswaramoorthy, S. Structural analysis of the catalytic and binding sites of Clostridium botulinum neurotoxin B. Nat. Struct. Biol. 2000, 7, 693-699.

16. Schiavo, G.; Rossetto, O.; Santucci, A.; DasGupta, B.R.; Montecucco, C. Botulinum neurotoxins are zinc protein. J. Biol. Chem. 1992, 267, 23479-23483.

17. Brunger, A.T.; Rummel, A. Receptor and substrate interactions of clostridial neurotoxins. Toxicon 2009, 54, 550-560.

18. Thanongsaksrikul, J. Therapeutic Antibodies for Disease Caused by Biological Weapon(s). Ph.D. Thesis, Mahidol University, Thailand, 2010.

19. Maksymowych, A.B.; Simpson, L.L. Binding and transcytosis of botulinum neurotoxin by polarized human colon carcinoma cells. J. Biol. Chem. 1998, 273, 21950-21957.

20. Rummel, A.; Eichner, T.; Weil, T.; Karnath, T.; Gutcaits, A.; Mahrhold, S.; Sandhoff, K.; Proia, R.L.; Acharya, K.R.; Bigalke, H.; Binz, T. Identification of the protein receptor binding site of botulinum neurotoxins B and G proves the double-receptor concept. Proc. Natl. Acad. Sci. USA 2007, 104, 359-364.

21. Dong, M.; Tepp, W.H.; Liu, H.; Johnson, E.A.; Chapman, E.R. Mechanism of botulinum neurotoxin B and G entry into hippocampal neurons. J. Cell. Biol. 2007, 179, 1511-1522.

22. Dong, M.; Yeh, F.; Tepp, W.H.; Dean, C.; Johnson, E.A.; Janz, R.; Chapman, E.R. SV2 is the protein receptor for botulinum neurotoxin A. Science 2006, 312, 592-596.

23. Schmidt, M.F.; Robinson, J.P.; DasGupta, B.R. Direct visualization of botulinum neurotoxin-induced channels in phospholipid vesicles. Nature 1993, 364, 827-830. 
24. Koriazova, L.K.; Montal, M. Translocation of botulinum neurotoxin light chain protease through the heavy chain channel. Nat. Struct. Biol. 2003, 10, 13-18.

25. Brunger. A.T.; Jin, R.; Breidenbach, M.A. Highly specific interaction between botulinum neurotoxins and synaptic vesicle proteins. Cell. Mol. Life Sci. 2008, 65, 2296-2306.

26. Schiavo, G.; Matteoli, M.; Montecucco, C. Neurotoxins affecting neuroexocytosis. Physiol. Rev. 2000, 80, 717-766.

27. Blasi, J.; Chapman, E.R.; Link, E.; Binz, T.; Yamasaki, S.; de Camilli, P.; Südhof, T.C.; Niemann, H.; Jahn, R. Botulinum neurotoxin A selectively cleaves the synaptic protein SNAP-25. Nature 1993, 365, 160-163.

28. Schiavo, G.; Rossetto, O.; Catsicas, S.; Polverino de Laureto, P.; DasGupta, B.R.; Benfenati, F.; Montecucco, C. Identification of the nerve terminal targets of botulinum neurotoxin serotypes A, D, and E. J. Biol. Chem. 1993, 268, 23784-23787.

29. Binz, T.; Blasi, J.; Yamasaki, S.; Baumeister, A.; Link, E.; Südhof, T.C.; Jahn, R.; Niemann, H. Proteolysis of SNAP-25 by types E and A botulinal neurotoxins. J. Biol. Chem. 1994, 269, 1617-1620.

30. Schiavo, G.; Shone, C.C.; Bennett, M.K.; Scheller, R.H.; Montecucco, C. Botulinum neurotoxin type $\mathrm{C}$ cleaves a single Lys-Ala bond within the carboxyl-terminal region of syntaxins. J. Biol. Chem. 1995, 270, 10566-10570.

31. Blasi, J.; Chapman, E.R.; Yamasaki, S.; Binz, T.; Niemann, H.; Jahn, R. Botulinum neurotoxin $\mathrm{C} 1$ blocks neurotransmitter release by means of cleaving HPC-1/syntaxin. EMBO J. 1993, 12, 4821-4828.

32. Schiavo, G.; Benfenati, F.; Poulain, B.; Rossetto, O.; de Laureto, P.P.; DasGupta, B.R.; Montecucco, C. Tetanus and botulinum-B neurotoxins block neurotransmitter release by proteolytic cleavage of synaptobrevin. Nature 1992, 359, 832-835.

33. Schiavo, G.; Shone, C.C.; Rossetto, O.; Alexander, F.C.; Montecucco, C. Botulinum neurotoxin serotype $\mathrm{F}$ is a zinc endopeptidase specific for VAMP/synaptobrevin. J. Biol. Chem. 1993, 268, 11516-11519.

34. Yamasaki, S.; Baumeister, A.; Binz, T.; Blasi, J.; Link, E.; Cornille, F.; Roques, B.; Fykse, E.M.; Südhof, T.; Jahn, R.; Niemann, H. Cleavage of members of the synaptobrevin/VAMP family by types D and F botulinal neurotoxins and tetanus toxin. J. Biol. Chem. 1994, 269, 12764-12772.

35. Yamasaki, S.; Binz, T.; Hayashi, T.; Szabo, E.; Yamasaki, N.; Eklund, M.; Jahn, R.; Niemann, H. Botulinum neurotoxin type $\mathrm{G}$ proteolyzes the Ala81-Ala82 bond of Rat synaptobrevin 2. Biochem. Biophys. Res. 1994, 200, 829-835.

36. Emmeluth, D. Botulism (Deadly Disease and Epidemics), 1st ed.; Chelsea House Publishers: Broomall, PA, USA, 2005.

37. Cenci di Bello, I.; Poulain, B.; Shone, C.C.; Tauc, L.; Dolly, J.O. Antagonism of the intracellular action of botulinum neurotoxin type A with monoclonal antibodies that map to light-chain epitopes. Eur. J. Biochem. 1994, 219, 161-169.

38. Anne, C.; Turcaud, S.; Quancard, J.; Teffo, F.; Meudal, H.; Fournié-Zaluski, M.C.; Roques, B.P. Development of potent inhibitors of botulinum neurotoxin type B. J. Med. Chem. 2003, 46, 4648-4656. 
39. Blommaert, A.; Turcaud, S.; Anne, C.; Roques, B.P. Small tripeptide surrogates with low nanomolar affinity as potent inhibitors of botulinum neurotoxin B metallo-proteolytic activity. Bioorg. Med. Chem. 2004, 12, 3055-3062.

40. Koenig, M.G. Trivalent botulinus antotoxin. Ann. Intern. Med. 1969, 70, 643-645.

41. Investigational heptavalent botulinum antitoxin (HBAT) to replace licensed botulinum antitoxin $\mathrm{AB}$ and investigational botulinum antitoxin E. MMWR 2010, 59, 299.

42. U.S. Food and Drug. Alphabetical List of Licensed Products: Information Updated through February 28, 2011. Available online: http://www.fda.gov/downloads/BiologicsBloodVaccines/ UCM149970.pdf (accessed on 27 March 2011).

43. Arnon, S.S.; Schechter, R.; Maslanka, S.E.; Jewell, N.P.; Hatheway, C.L. Human botulism immune globulin for the treatment of infant botulism. N. Engl. J. Med. 2006, 354, 462-471.

44. Arnon, S.S. Creation and development of the public service orphan drug human botulism immune globulin. Pediatrics 2007, 119, 785-789.

45. Nowakowski, A.; Wang, C.; Powers, D.B.; Amersdorfer, P.; Smith, T.J.; Montgomery, V.A.; Sheridan, R.; Blake, R.; Smith, L.A.; Marks, J.D. Potent neutralization of botulinum neurotoxin by recombinant oligoclonal antibody. Proc. Natl. Acad. Sci. USA 2002, 99, 11346-11350.

46. Levy, R.; Forsyth, C.M.; LaPorte, S.L.; Geren, I.N.; Smith, L.A.; Marks, J.D. Fine and Domain-level epitope mapping of botulinum neurotoxin type A neutralizing antibodies by yeast surface display. J. Mol. Biol. 2007, 365, 196-210.

47. Lou, J.; Geren, I.; Garcia-Rodriguez, C.; Forsyth, C.M.; Wen, W.; Knopp, K.; Brown, J.; Smith, T.; Smith, L.A.; Marks, J.D. Affinity maturation of human botulinum neurotoxin antibodies by light chain shuffling via yeast mating. Protein Eng. Des. Sel. 2010, 23, 311-319.

48. Atassi, M.Z. Immune recognition of BoNTs A and B: how anti-toxin antibodies that bind to the heavy chain obstruct toxin action. Toxicon 2009, 54, 600-613.

49. Cheng, L.W.; Stanker, L.H.; Henderson, T.D., II; Lou, J.; Marks, J.D. Antibody protection against botulinum neurotoxin intoxication in mice. Infect. Immun. 2009, 77, 4305-4313.

50. Keller, M.A.; Stiehm, E.R. Passive immunity in prevention of infectious diseases. Clin. Microbiol. Rev. 2000, 13, 602-614.

51. Ellis, M.; Chir, B. Human antitetanus serum in the treatment of tetanus. Br. Med. J. 1963, 1, 1123-1126.

52. Gallagher, J.R. Use of convalescent measles serum to control measles in a preparatory school. Am. J. Public Health Nations Health 1935, 25, 595-598.

53. Casadevall, A.; Pirofski, L.A. New concepts in antibody-mediated immunity. Infect. Immun. 2004, 72, 6191-6196.

54. Orange, J.S.; Hossny, E.M.; Weiler, C.R.; Ballow, M.; Berger, M.; Bonilla, F.A.; Buckley, R.; Chinen, J.; El-Gamal, Y.; Mazer, B.D.; Nelson, R.P., Jr.; Patel, D.D.; Secord, E.; Sorensen, R.U.; Wasserman, R.L.; Cunningham-Rundles, C. Use of intravenous immunoglobulin in human disease: A review of evidence by members of the primary immunodeficiency committee of the American academy of allergy, asthma and immunology. J. Allerg. Clin. Immunol. 2006, 117, 525-553. 
55. Deng, Y-Q.; Dai, J-X.; Ji, G-H.; Jiang, T.; Wang, H-J.; Yang, H.; Tan, W-L.; Liu, R.; Yu, M.; Ge, B-X.; Zhu, Q-Y.; Qin, E-D.; Guo, Y-J.; Qin, C-F. A broadly Flavivirus cross-neutralizing monoclonal antibody that recognizes a novel epitope within fushion loop of E protein. PLoS ONE 2011, 6, e16059.

56. Blanchard, T.G.; Czinn, S.J.; Maurer, R.; Thomas, W.; Soman, G.; Nedrud, J.G. Urease-specific monoclonal antibodies prevent Helicobacter felis infection in mice. Infect. Immun. 1995, 63, 1394-1399.

57. Colomar, M.; Puga, I.; López, M.; Massot, M.; Jorquera, J.I.; Reina, M.; Vilaró, S.; Espel, E. Neutralization of measles virus infectivity and antibody-dependent cell-mediated cytotoxicity activity against an Epstein-Barr virus-infected cell line by intravenous administration of immunoglobulin G. Clin. Diagn. Lab. Immunol. 2003, 10, 751-756.

58. Han, Y.; Kozel, T.R.; Zhang, M.X.; MacGill, R.S.; Carroll, M.C.; Cutler, J.E. Complement is essential for protection by an $\operatorname{IgM}$ and an $\operatorname{IgG} 3$ monoclonal antibody against experimental hematogenously disseminated candidiasis. J. Immunol. 2001, 167, 1550-1557.

59. Köhler, G.; Milstein, C. Continuous cultures of fused cells secreting antibody of predefined specificity. Nature 1975, 256, 495-497.

60. Haurum, J.S. Recombinant polyclonal antibodies: The next generation of antibody therapeutics? Drug Discov. Today 2006, 11, 655-660.

61. Casadevall, A.; Scharff, M.D. Return to the past: The case for antibody-based therapies in infectious diseases. Clin. Infect. Dis. 1995, 21, 150-161.

62. Nelson, A.L.; Reichert, J.M. Development trends for therapeutic antibody fragments. Nat. Biotechnol. 2009, 27, 331-337.

63. Li, J.; Zhu, Z. Research and development of next generation of antibody-based therapeutics. Acta. Pharmacol. Sin. 2010, 31, 1198-1207.

64. Mazuet, C.; Dano, J.; Popoff, M.R.; Créminon, C.; Volland, H. Characterization of botulinum neurotoxin type A neutralizing monoclonal antibodies and influence of their half-lives on therapeutic activity. PLOS ONE 2010, 5, e12416.

65. Köhler, G. Immunoglobulin chain loss in hybridoma lines. Proc. Natl. Acad. Sci. USA 1980, 77, 2197-2199.

66. Courtenay-Luck, N.S.; Epenetos, A.A.; Winearls, C.G.; Ritter, M.A. Preexisting human anti-murine immunoglobulin reactivity due to polyclonal rheumatoid factors. Cancer Res. 1987, 47, 4520-4525.

67. Tjandra, J.J.; Ramadi, L.; McKenzie, I.F.C. Development of human anti-murine antibody (HAMA) response in patients. Immunol. Cell Biol. 1990, 68, 367-376.

68. Losman, M.J.; DeJager, R.L.; Monostier, M.; Sharkey, R.M.; Goldenberg, D.M. Human immune response to anti-carcinoembryonic antigen murine monoclonal antibodies. Cancer Res. 1990, 1, $1055-1058$.

69. Morrison, S.L.; Johnson, M.J.; Herzenberg, L.A.; Oi, V.T. Chimeric human antibody molecules: Mouse antigen-binding domains with human constant region domains. Proc. Natl. Acad. Sci. USA 1984, 81, 6851-6855.

70. Stern, M.; Herrmann, R. Overview of monoclonal antibodies in cancer therapy: Present and promise. Crit. Rev. Oncol. Hematol. 2005, 54, 11-29. 
71. Normann , S.J. Why antibody inhibits vascular clearance of staphylococcal enterotoxin B. J. Immunol. 1970, 104, 673-678.

72. Devaux C.; Moreau, E.; Goyffon, M.; Rochat, H.; Billiald, P. Construction and functional evaluation of a single-chain antibody fragment that neutralizes toxin AahI from the venom of the scorpion Androctonus australis hector. Eur. J. Biochem. 2001, 268, 694-702.

73. Christensen, E.I.; Verrous, P.J.; Nielsen, R. Receptor-mediated endocytosis in renal proximal tubule. Pflug. Arch. Eur. J. Phys. 2009, 458, 1039-1048.

74. Riechmann, L.; Clark, M.; Waldmann, H.; Winter, G. Reshaping human antibodies for therapy. Nature 1988, 332, 323-327.

75. Maneewatch, S.; Sakolvaree, Y.; Tapchaisri, P.; Saengjaruk, P.; Songserm, T.; Wongratanachewin, S.; Tongtawe, P.; Srimanote, P.; Chaisri, U.; Chaicumpa, W. Humanized-monoclonal antibody against heterologous Leptospira infection. Protein Eng. Des. Sel. 2009, 22, 305-312.

76. Reichert, J.; Pavlou, A. Monoclonal antibodies market. Nat. Rev. Drug Discov. 2004, 3, 383-384.

77. Brüggemannand, M.; Taussig, M.J. Production of human antibody repertoires in transgenic mice. Curr. Opin. Biotechnol. 1997, 8, 455-458.

78. Chiorazzi, N.; Wasserman, R.L.; Kunkel, H.G. Use of Epstein-Barr virus-transformed B cell lines for the generation of immunoglobulin-producing human B cell hybridomas. J. Exp. Med. 1982, 156, 930-935.

79. Rosen, A.; Persson, K.; Klein, G. Human monoclonal antibodies to a genus-specific chlamydial antigen produced by EBV-transformed B cells. J. Immunol. 1983, 130, 2899-2902.

80. Garzelli, C.; Puglisi, C.; Falcone, G. Human monoclonal antibody to purified protein derivative of tuberculin produced by hybrids constructed with Epstein-Barr virus-transformed B lymphocytes and mouse myeloma cells. Eur. J. Immunol. 1986, 16, 584-587.

81. Foung, S.K.H.; Perkins, S.; Raubitschek, A.; Larrick, J.; Lizak, G.; Fishwild, D.; Engleman, E.G.; Grumet, F.C. Rescue of human monoclonal antibody production from an EBV-transformed B cell line by fusion to a human-mouse hybridoma. J. Immunol. Methods 1984, 70, 83-90.

82. Goldsby, R.A.; Kindt, T.J.; Osborne, B.A. Kuby Immunology, 5th ed.; W.H. Freeman and Company: New York, NY, USA, 2003; Chapter 5, pp. 105-136.

83. Maizels, N. Immunoglobulin gene diversification. Annu. Rev. Genet. 2005, 39, 23-46.

84. Boder, E.T.; Wittrup, K.D. Yeast surface display for screening combinatorial polypeptide libraries. Nat. Biotechnol. 1997, 15, 553-557.

85. Daugherty, P.S.; Olsen, M.J.; Iverson, B.L.; Georgiou, G. Development of an optimized expression system for the screening of antibody libraries displayed on the Escherichia coli surface. Protein Eng. 1999, 12, 613-621.

86. Beerli, R.R.; Bauer, M.; Buser, R.B.; Gwerder, M.; Muntwiler, S.; Maurer, P.; Saudan, P.; Bachmann, M.F. Isolation of human monoclonal antibodies by mammalian cell display. Proc. Natl. Acad. Sci. USA 2008, 105, 14336-14341.

87. Hanes, J.; Plückthun, A. In vitro selection and evolution of functional proteins by using ribosome display. Proc. Natl. Acad. Sci. USA 1997, 94, 4937-4942. 
88. Smith, G.P. Filamentous fusion phage: Novel expression vectors that display cloned antigens on the virion surface. Science 1985, 228, 1315-1317.

89. Hoogenboom, H.R. Selecting and screening recombinant antibody libraries. Nat. Biotechnol. 2005, 23, 1105-1116.

90. Kulkeaw, K.; Sakolvaree, Y.; Srimanote, P.; Tongtawe, P.; Maneewatch, S.; Sookrung, N.; Tungtrongchitr, A.; Tapchaisri, P.; Kurazono, H.; Chaicumpa, W. Human monoclonal ScFv neutralize lethal Thai cobra, Naja kaouthia, neurotoxin. J. Proteomics 2009, 72, 270-282.

91. Hoogenboom, H.R. Overview of antibody phage-display technology and its applications. In Antibody Phage Display: Methods and Protocols; O'Brien, P.M., Aitken, R., Eds.; Humana Press Inc.: Totowa, NJ, USA, 2002; pp. 1-37.

92. Sidhu, S.S.; Fellouse, F.A. Synthetic therapeutic antibodies. Nat. Chem. Biol. 2006, 2, 682-688.

93. Winter, G.; Griffiths, A.D.; Hawkins, R.E.; Hoogenboom, H.R. Making antibodies by phage display technology. Annu. Rev. Immunol. 1994, 12, 433-455.

94. de Haard, H.J.; Kazemier, B.; van der Bent, A.; Oudshoorn, P.; Boender, P.; van Gemen, B.; Arends, J.W.; Hoogenboom, H.R. Absolute conservation of residue 6 of immunoglobulin heavy chain regions of class IIA is required for correct folding. Protein Eng. 1998, 11, 1267-1276.

95. Maneewatch, S.; Thanongsaksrikul, J.; Songserm, T.; Theung-In, K.; Kulkeaw, K.; Thathisong, U.; Srimanote, P.; Tongtawe, P.; Tapchaisri P.; Chaicumpa, W. Human single-chain antibodies that neutralize homologous and heterologous strains and clades of influenza A virus subtype H5N1. Antivir. Ther. 2009, 14, 221-230.

96. Poungpair, O.; Chaicumpa, W.; Kulkeaw, K.; Maneewatch, S.; Theung-In, K.; Srimanote, P.; Tongtawe, P.; Songserm, T.; Lekcharoensuk, P.; Tapchaisri, P. Human single chain monoclonal antibody that recognizes matrix protein of heterologous influenza A virus subtype. J. Virol. Methods 2009, 159, 105-111.

97. Thanongsaksrikul, J.; Srimanote, P.; Maneewatch. S.; Choowongkomon, K.; Tapchaisri, P.; Makino, S.; Kurazono, H.; Chaicumpa, W. A $\mathrm{V}_{\mathrm{H}} \mathrm{H}$ that neutralizes the zinc metalloproteinase activity of botulinum neurotoxin type A. J. Biol. Chem. 2010, 285, 9657-9666.

98. Joosten, V.; Lokman, C.; van den Hondel, C.A.; Punt, P.J. The production of antibody fragments and antibody fusion proteins by yeasts and filamentous fungi. Microb. Cell. Fact. 2003, 2, 1-15.

99. Hamers-Casterman, C.; Atarhouch, T.; Muyldermans, S.; Robinson, G.; Hamers, C.; Songa, E.B.; Bendahman, N.; Hamers, R. Naturally occurring antibodies devoid of light chains. Nature 1993, 363, 446-448.

100. Davies, J.; Riechmann, L. Camelising human antibody fragments: NMR studies on VH domains. FEBS Lett. 1994, 339, 285-290.

101. Muyldermans, S.; Atarhouch, T.; Saldanha, J.; Barbosa, J.A.; Hamers, R. Sequence and structure of $\mathrm{VH}$ domain from naturally occurring camel heavy chain immunoglobulins lacking light chains. Protein Eng. 1994, 7, 1129-1135.

102. Nguyen, V.K.; Hamers, R.; Muyldermans, S. Camel heavy-chain antibodies: Diverse germline $\mathrm{V}(\mathrm{H}) \mathrm{H}$ and specific mechanisms enlarge the antigen-binding repertoire. EMBO J. 2000, 19, 921-930.

103. Conrath, K.E.; Wernery, U.; Muyldermans, S.; Nguyen, V.K. Emergence and evolution of functional heavy-chain antibodies in Camelidae. Dev. Comp. Immunol. 2003, 27, 87-103. 
104. Wu, T.T.; Johnson, G.; Kabat, E.A. Length distribution of CDRH3 in antibodies. Proteins 1993, $16,1-7$.

105. Muyldermans, S. Single domain camel antibodies: Current status. J. Biotechnol. 2001, 74, 277-302.

106. Desmyter, A.; Decanniere, K.; Muyldermans, S.; Wyns, L. Antigen specificity and high affinity binding provided by one single loop of a camel single-domain antibody. J. Biol. Chem. 2001, 276, 26285-26290.

107. de Genst, E.; Silence, K.; Decannierer, K.; Conrath, K.; Loris, R.; Kinne, J.; Muyldermans, S.; Wyns, L. Molecular basis for the preferential cleft recognition by dromedary heavy-chain antibodies. Proc. Natl. Acad. Sci. USA 2006, 103, 4586-4591.

108. Lauwereys, M.; Ghahroudi, M.A.; Desmyter, A.; Kinne, J.; Holzer, W.; de Genst, E.; Wyn, L.; Muyldermans, S. Potent enzyme inhibitors derived from dromedary heavy-chain antibodies. EMBO J. 1998, 17, 3512-3520.

109. Conrath, K.E.; Lauwereys, M.; Galleni, M.; Matagne, A.; Frere, J.M.; Kinne, J.; Wyn, L.; Muyldermans, S. $\beta$-lactamase inhibitors derived from single-domain antibody fragments elicited in the Camelidae. Antimicrob. Agents Chemother. 2001, 45, 2807-2812.

110. Ghahroudi, M.A.; Desmyter, A.; Wyns, L.; Hamers, R.; Muyldermans, S. Selection and identification of single domain antibody fragments from camel heavy-chain antibodies. FEBS Lett. 1997, 414, 521-526.

111. Harmsen, M.M.; de Haard, H.J. Properties, production, and applications of camelid single-domain antibody fragments. Appl. Microbiol. Biotechnol. 2007, 77, 13-22.

112. Chulanetra, M.; Chaicumpa, W. Human antibody that neutralizes tetrodotoxin. Mahidol University, Thailand. Unpublished work, 2011.

113. Muyldermans, S.; Cambillau, C.; Wyns, L. Recognition of antigens by single domain antibody fragments: The superfluous luxury of paired domains. TIBS 2001, 26, 230-235.

114. Dong, J.; Thompson, A.A.; Fan, Y.; Lou, J.; Conrad, F.; Ho, M.; Pires-Alves, M.; Wilson, B.A.; Stevens, R.C.; Marks, J.D. A single-domain llama antibody potently inhibits the enzymatic activity of botulinum neurotoxin by binding to the non-catalytic $\alpha$-exosite binding region. J. Mol. Biol. 2010, 397, 1106-1118.

115. Conway, J.O.; Sherwood, L.J.; Collazo, M.T.; Garza, J.A.; Hayhurst, A. Llama single domain antibodies specific for the 7 botulinum neurotoxin serotypes as heptaplex immunoreagents. PLoS ONE 2010, 5, e8818.

116. Derossi, D.; Joliot, A.H.; Chassaing, G.; Prochiantz, A. The third helix of the Antennapedia homeodomain translocates through biological membranes. J. Biol. Chem. 1994, 269, 10444-10450.

117. Pooga, M.; Hallbrink, M.; Zorko, M.; Langel, U. Cell penetration by transpotan. FASEB J. 1998, 12, 67-77.

118. Poungpair, O.; Pootong, A.; Maneewatch, S.; Srimanote, P.; Tongtawe, P.; Songserm, T.; Tapchaisri, P.; Chaicumpa,W. A human single chain transbody specific to matrix protein (M1) interferes with the replication of Influenza A virus. Bioconjugate Chem. 2010, 21, 1134-1141.

119. Noguchi, H.; Matsumoto, S. Protein transduction technology: A novel therapeutic perspective. Acta Med. Okayama 2006, 60, 1-11. 
120. Lundberg, M.; Johansson, M. Is VP22 nuclear homing an artifact? Nat. Biotechnol. 2001, 19, 713-714.

121. Letoha, T.; Gaal, S.; Somlai, C.; Czajlik, A.; Perczel, A.; Penke, B. Membrane translocation of penetratin and its derivatives in different cell lines. J. Mol. Recognit. 2003, 16, 272-279.

122. Saalik, P.; Elmquist, A.; Hansen, M.; Padari, K.; Saar, K.; Viht, K.; Langel, U.; Pooga, M. Protein cargo delivery properties of cell-penetrating peptides: A comparative study. Bioconjugate Chem. 2004, 15, 1246-1253.

123. Kaplan, I.M.; Wadia, J.S.; Dowdy, S.F. Cationic TAT peptide transduction domain enters cells by macropinocytosis. J. Control. Release 2005, 102, 247-253.

124. Richard, J.P.; Melikov, K.; Brooks, H.; Prevot, P.; Lebleu, B.; Chernomordik, L.V. Cellular uptake of unconjugated TAT peptide involves clathrin-dependent endocytosis and heparin sulfate receptors. J. Biol. Chem. 2005, 280, 15300-15306.

125. Morris, M.C.; Deshayes, S.; Heitz, F.; Divita, G. Cell-penetrating peptides: From molecular mechanisms to therapeutics. Biol. Cell 2008, 100, 201-217.

126. Raha, S.; Paunesku, T.; Woloschak, G. Peptide-mediated cancer targeting of nanoconjugates. WIREs Nanomed. Nanobiotechnol. 2010, 3, 269-281.

127. Deshayes, S.; Morris, M.C.; Divita, G.; Heitz, F. Cell-penetrating peptides: Tools for intracellular delivery of therapeutics. Cell Mol. Life Sci. 2005, 62, 1839-1849.

(C) 2011 by the authors; licensee MDPI, Basel, Switzerland. This article is an open access article distributed under the terms and conditions of the Creative Commons Attribution license (http://creativecommons.org/licenses/by/3.0/). 